\title{
Magnetic nanoparticles sensitize MCF-7 breast cancer cells to doxorubicin-induced apoptosis
}

\author{
Khaled Aljarrah ${ }^{1 *}$, Nizar M Mhaidat ${ }^{3}$, M-Ali H Al-Akhras ${ }^{1}$, Ahmad N Aldaher ${ }^{3}$, BA Albiss ${ }^{2}$, Khaled Aledealat $^{1}$ and \\ Fawzi M Alsheyab
}

\begin{abstract}
Background: Resistance of breast cancer cells to the available chemotherapeutics is a major obstacle to successful treatment. Recent studies have shown that magnetic nanoparticles might have significant application in different medical fields including cancer treatment. The goal of this study is to verify the ability of magnetic nanoparticles to sensitize cancer cells to the clinically available chemotherapy.

Methods: The role of iron oxide nanoparticles, static magnetic field, or a combination in the enhancement of the apoptotic potential of doxorubicin against the resistant breast cancer cells, MCF-7 was evaluated using the MTT assay and the propidium iodide method.

Results: In the present study, results revealed that pre-incubation of MCF-7 cells with iron oxide nanoparticles before the addition of doxorubicin did not enhance doxorubicin-induced growth inhibition. Pre-incubation of MCF-7 cells with iron oxide nanoparticles followed by a static magnetic field exposure significantly $(P<0.05)$ increased doxorubicin-induced cytotoxicity. Sensitization with pre-exposure to the magnetic field was dose-dependent where the highest cytotoxicity was seen at 1 tesla. Further experiments revealed that the anti-proliferative effect of this treatment procedure is due to induction of apoptotic cell death.
\end{abstract}

Conclusions: These results might point to the importance of combining magnetic nanoparticles with a static magnetic field in treatment of doxorubicin-refractory breast cancer cells.

Keywords: Nanoparticles, MCF-7, Doxorubicin, Breast cancer

\section{Background}

Breast cancer is the most commonly diagnosed cancer among females world-wide. There are currently more than one million women worldwide fighting breast cancer, accounting for more than one-fifth of the global burden of cancers. In more developed and less developed countries, incidence rates vary widely, ranging from age-standardized rate 20.7 in Uganda to 90.7 in the USA per 100,000 [1]. In Europe, 421,000 cases of breast cancer among women were estimated in 2008 [2] and it is estimated that 184,450 new cases of invasive stages were diagnosed in the USA in 2008 and 230,480 in 2011 [3]. In Jordan, according to the Jordan Cancer Registry's 2008 Cancer Incidence in Jordan Report, breast cancer constituted $35.3 \%$ of all cancer cases in women [4].

\footnotetext{
* Correspondence: kjarrah@just.edu.jo

${ }^{1}$ Biophysics laboratory, Jordan University of Science and Technology, Irbid, Jordan

Full list of author information is available at the end of the article
}

Resistance of breast cancer cells to available chemotherapeutics is a major obstacle to successful treatment. Although the cure rate from excision of the primary tumor is high, once the disease spreads to distant sites it is usually incurable by current systemic therapies, such as chemotherapy, radiotherapy, hormonal therapy and immunotherapy. The development of a novel approach for early detection, treatment and overcoming resistance of cancers is potentially required [5].

Anthracyclines are some of the most commonly used anticancer agents. The first generation of anthracyclines were isolated from the pigment-producing Streptomyces peucetius and were named doxorubicin and daunorubicin [6]. Doxorubicin (Adriamycin), a powerful drug in the fight against cancer, joined the oncologic practice in the late 1960s [7]. It exerts antitumor activity through its inhibition of topoisomerase II, and thus prevents chain unfolding and separation in DNA replication as well as
Ciomed Central

(C) 2012 Aljarrah et al.; licensee BioMed Central Ltd. This is an Open Access article distributed under the terms of the Creative Commons Attribution License (http://creativecommons.org/licenses/by/2.0), which permits unrestricted use, distribution, and reproduction in any medium, provided the original work is properly cited. 
DNA repair. This ultimately leads to cell death, called apoptosis. Other mechanisms that might be involved are intercalating into DNA, resulting in inhibition of DNA synthesis and function, and formation of cytotoxic oxygen free radicals that results in single- and double-stranded DNA breaks with subsequent inhibition of DNA synthesis and function.

Iron oxide nanoparticles have been employed in many biomedical applications due to their attractive properties, such as stability over time, biocompatibility and sensitivity to a magnetic field. Furthermore, their capability in many potential applications in biology and medicine has been explored, such as a contrast agent in magnetic resonance imaging (MRI) [8-12], a carrier in drug delivery [13-17], and as heating agents in the presence of alternating magnetic fields. This property can be very efficient in killing cancer cells through hyperthermia since these magnetic particles can be guided to the tumor by the external magnetic field gradient [18-23]. Furthermore, recent study has shown that the application of the static magnetic field in the presence of these particles can reduce cell viability, apoptosis and cell cycle aberrations [24].

In the present study, we hypothesized that magnetic nanoparticles might have anticancer activity or are able to sensitize cancer cells to the clinically available chemotherapy.

\section{Methods}

\section{Cell line}

Human breast cancer cell line MCF-7 was generously provided by Dr. Rick F. Thorne, from the Newcastle University, NSW, Australia, and cultured in DMEM containing 10\% FCS (Bio Whittaker, Verviers, Belgium).

\section{Chemical reagents}

Doxorubicin, purchased from Sigma-Aldrich (St. Louis, MO, USA), was dissolved in dimethyl sulfoxide (DMSO) and made up in a stock solution of $1 \mathrm{mM}$. Iron oxide nanoparticles coated by PVP (polyvinyl pyrorolidone), Propidium Iodide and 3-(4,5-dimethylthiazol-2-yl)-2,5diphenyltetrazolium bromide (MTT) were purchased from Sigma Aldrich (Sigma-Aldrich).

\section{Preparation of the $\mathrm{Fe}_{2} \mathrm{O}_{3}$ nanoparticles}

$\mathrm{FeCl}_{3} \cdot 6 \mathrm{H}_{2} \mathrm{O}$ (Sigma Aldrich, $>99 \%$ ) and glycine (Sigma Aldrich, 99\%) were mixed to create a solution of $0.1 \mathrm{M}$ $\mathrm{Fe} 3+, 0.2 \mathrm{M}$ glycine with a total volume of $50 \mathrm{~mL}$. The solution was then transferred to a Teflon-lined stainless steel vessel. The vessel was tightly sealed and heated to $150^{\circ} \mathrm{C}$ for 10 hours and slowly cooled to room temperature. The $\mathrm{pH}$ of the solution was controlled before and after the hydrothermal process. The precipitate powder was washed repeatedly with deionized water as well as absolute ethanol and sonicated for 5 minutes prior to filtering and drying in a vacuum for 10 hours. The morphology and the microstructure of the powder were characterized using X-ray diffraction (XRD) and scanning electron microscope (SEM). The average size of the spherical-shaped nanoparticles was found to be about $50 \mathrm{~nm}$. A representative micrograph of the nanoparticles is shown in Figure 1 (the scale bar is $50 \mathrm{~nm}$ ).

\section{Cell viability assays}

The acute cytotoxic effect of doxorubicin and drug combinations on MCF-7 cells was determined using MTT assays as described previously [25]. Briefly, cells were seeded at 5,000/well onto flat-bottomed 96-well culture plates and allowed to grow for 24 hours before the desired treatment. Cells were then labeled with MTT from the Vybrant MTT Cell Proliferation Assay Kit (Molecular Probes, Eugene, OR, USA) according to the manufacturer's instruction and the resulting formazan was solubilized with DMSO. Absorbance was read in a microplate reader at $540 \mathrm{~nm}$.

\section{Apoptosis}

Quantitation of apoptotic cells by measurement of sub-G1 DNA content using the PI method was carried out as described elsewhere [26]. In brief, MCF-7 cells were adhered overnight in a 24-well plate and incubated with different treatment combinations. Floating and adherent cells were then harvested and incubated overnight at $4^{\circ} \mathrm{C}$ in the dark with $750 \mu \mathrm{l}$ of a hypotonic buffer $(50 \mu \mathrm{g} / \mathrm{mL}$ PI in $0.1 \%$ sodium citrate plus $0.1 \%$ Triton X-100; Sigma) before flow cytometric analysis using a FACScan flow cytometer (Becton Dickinson, San Jose, CA, USA).

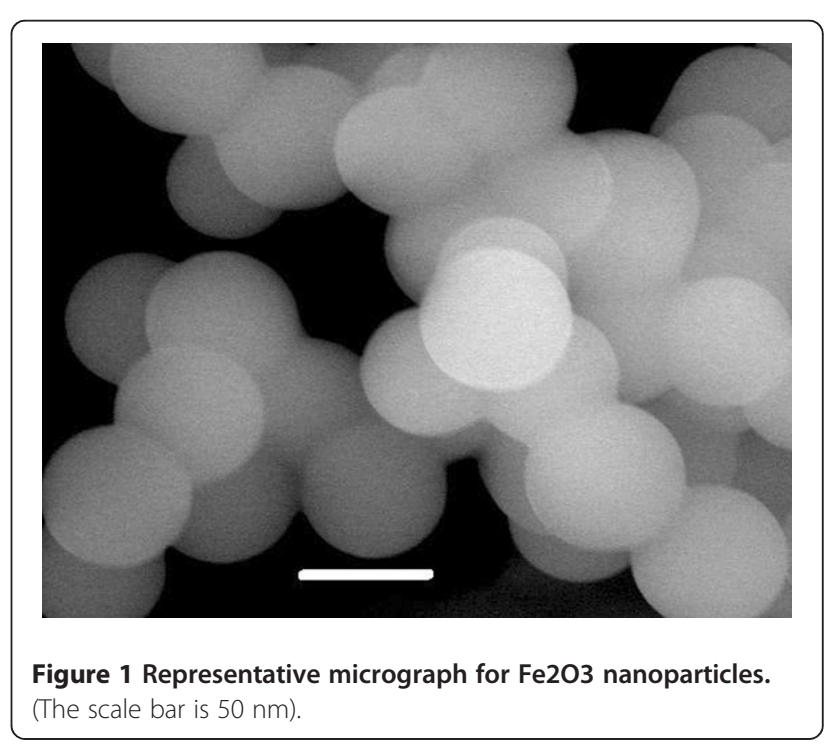




\section{Statistical analysis}

Data are expressed as mean \pm SE. The statistical significance of intergroup differences in normally distributed continuous variables was determined using Student's $t$-test. $P$-values $\leq 0.05$ were considered statistically significant. $P$-values $\leq 0.05$ and $\leq 0.001$ are indicated by* and $*$, respectively.

\section{Results and discussion}

In the present study, we evaluated the potential of spherical iron oxide nanoparticles $\left(\mathrm{Fe}_{2} \mathrm{O}_{3}\right)$ to sensitize MCF-7 breast cancer cells to doxorubicin-induced cytotoxicity. MCF-7 cells were pre-incubated with or without $\mathrm{Fe}_{2} \mathrm{O}_{3}$ (at $0.5 \mathrm{mM}$ ) for 16 hours before the addition of doxorubicin at $1 \mu \mathrm{M}$ for another 72 hours. As shown in Figure 2, pre-incubation with $\mathrm{Fe}_{2} \mathrm{O}_{3}$ did not induce cytotxic effect against MCF-7 cells and did not sensitize MCF-7 cells to doxorubicin-induced cell growth inhibition. Unlike previous reports [24], these results showed that iron oxide nanoparticles might not be the predominant source of the cytotoxicity.

Previous studies have shown that nanoparticles hold promise for a variety of biomedical applications due to their properties of Visualization under magnetic resonance imaging (MRI), heating with radio frequency and movement in an external magnetic field. Magnetic guidance is one of the strategies for the accumulation of nanoparticles and drugs in an affected area. To study the effect of static magnetic field (SMF) on cytotoxicity induced up on treatment with a combination of doxorubicin and $\mathrm{Fe}_{2} \mathrm{O}_{3}$, different strengths of SMF were used. Results in Figure 3 show that pre-exposure to SMF at different strengths did not sensitize cancer cells when treated with doxorubicin alone.

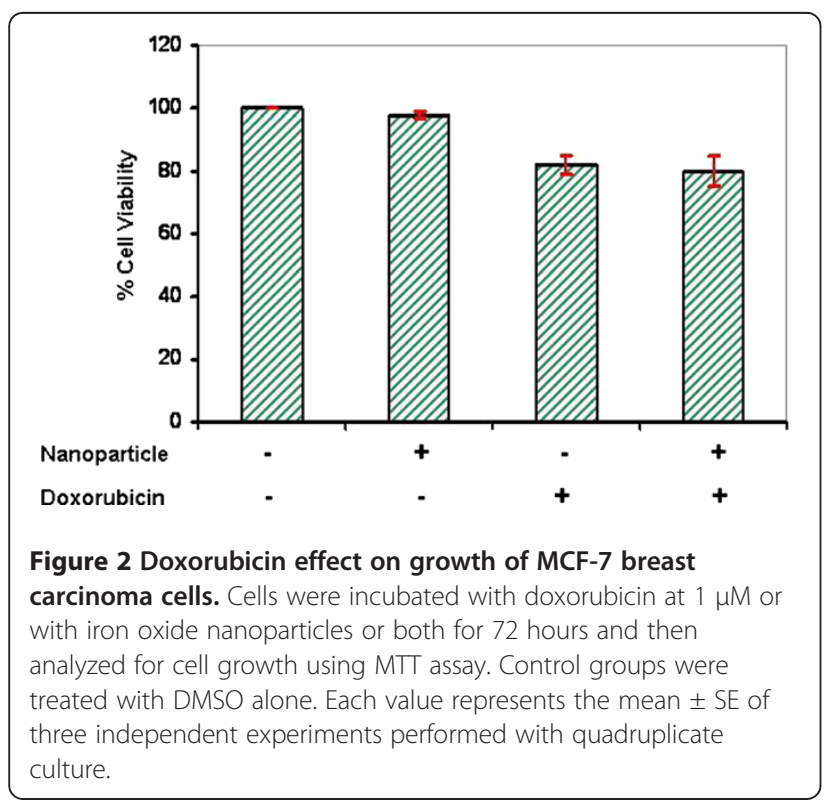

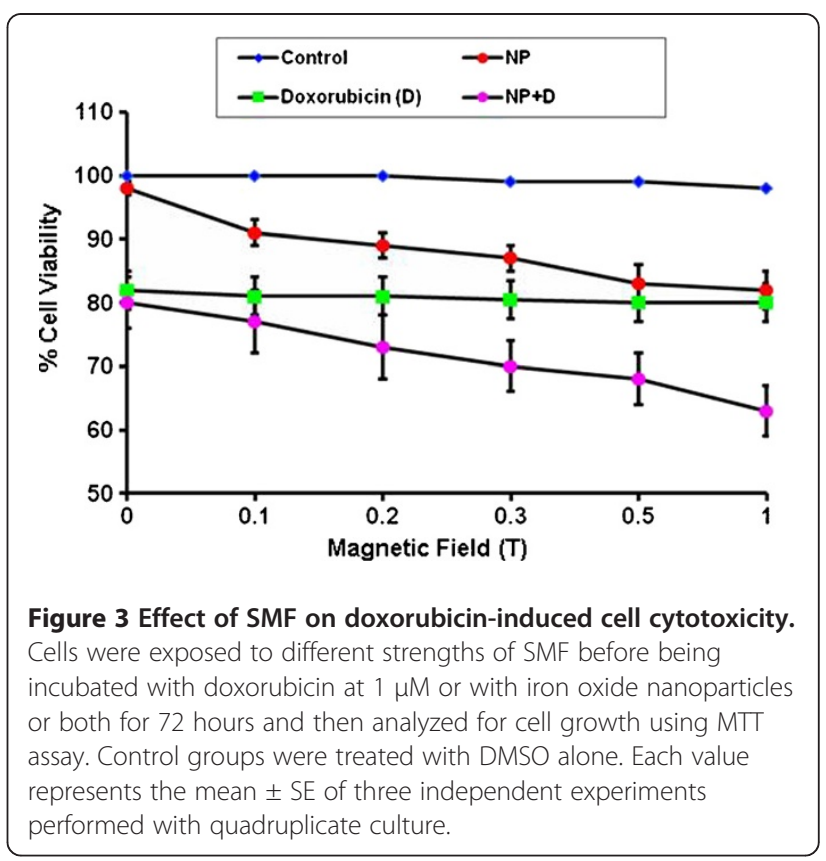

Moreover, sensitization of cancer cells to doxorubicin by SMF was dose-dependent and seemed to be $\mathrm{Fe}_{2} \mathrm{O}_{3}$ dependent.

We next studied if the growth inhibition occurred by pre-exposure to SMF was due to induction of cellular death. MCF-7 cells were pre-incubated with $\mathrm{Fe}_{2} \mathrm{O}_{3}$ for 16 hours before they were exposed to SMF at 1 tesla and followed by the addition of doxorubicin for another 72 hours. As shown in Figure 4, cells pre-incubated with $\mathrm{Fe}_{2} \mathrm{O}_{3}$ and exposed to the SMF before the treatment with doxorubicin experienced a significant $(P<0.05)$ increase

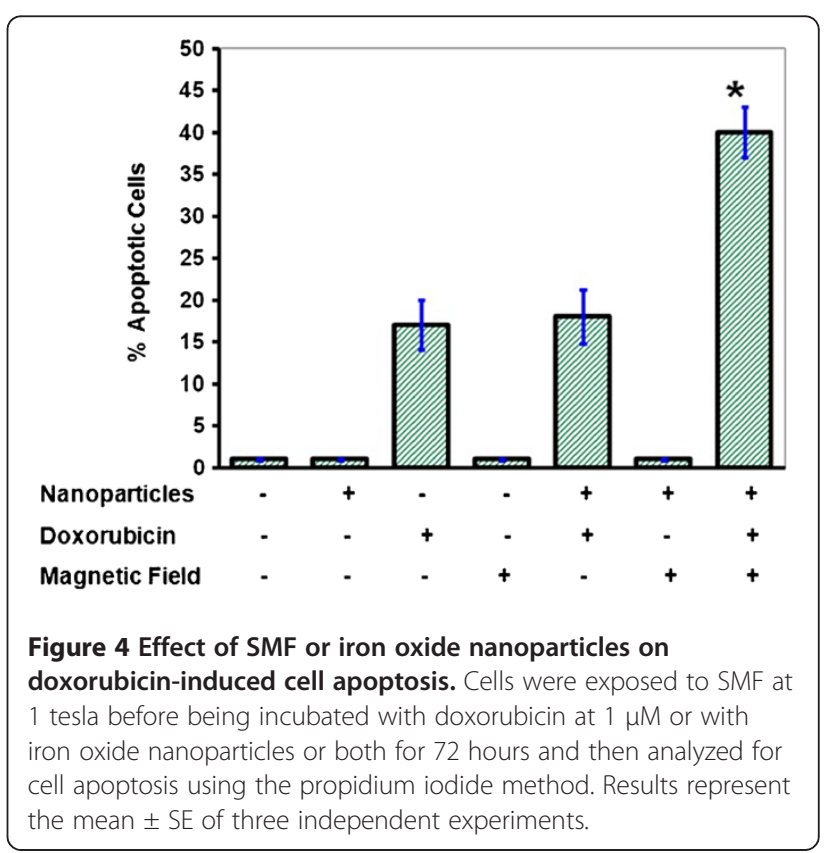


in the sub-G1 DNA fragmentation indicating that such treatment might sensitize cancer cells to doxorubicininduced apoptotic cell death.

Several cellular compartments, such as lipids, carbohydrates and nucleic acids, might be damaged by increased levels of reactive oxygen species (ROS) in that increased levels of ROS might induce irreversible damage to DNA $[27,28]$. Cell death inducers, such as chemotherapy and ionizing radiotherapy, have been shown to induce their cytotoxicity through ROS generation [29-32]. Our results showed that treatment with $\mathrm{Fe}_{2} \mathrm{O}_{3}$ particles alone are unable to inhibit cancer cell growth largely due to the inability to generate ROS (data not shown). Other studies showed that in the presence of a SMF, $\mathrm{FeCl}_{2}$ induces DNA damage in an ROS-dependent manner indicating that SMF, somehow, has a role in activating $\mathrm{ROS}$ generation from $\mathrm{FeCl}_{2}$ [33-35]. This might be not the situation in the present study since $\mathrm{FeCl}_{2}$ has been removed by nanoparticle washing. Consistent with our studies, it has been shown that SMF induces apoptotic cell death, particularly in human transformed cells and in rat tendon fibroblasts cell cultures [36-39]. Furthermore, results in the present study revealed that the SMF without the addition of the ROS generator, $\mathrm{Fe}_{2} \mathrm{O}_{3}$, or the ROS inducer, doxorubicin, is unable to induce cancer cell growth inhibition. This was consistent with previous studies showing that SMF did not enhance the rate of apoptotic cells without the addition of hydrogen peroxide [40].

The apoptotic potential of SMF might be due to the ability of SMF to induce marked alteration in cellular shape [41]. In addition to the oxidative stress induced by $\mathrm{Fe}_{2} \mathrm{O}_{3}$, this effect might lead to physical stress that will modulate the intracellular levels of calcium. Alteration in the intracellular levels of calcium has been shown to induce a response called unfolded protein response (UPR). The later occurs due to increased accumulation of misor malfolded proteins. Persistence of UPR signaling in presence of doxorubicin and $\mathrm{Fe}_{2} \mathrm{O}_{3}$, the cell will die by induction of the endoplasmic reticulum (ER) stress [42].

Another proposed mechanism for cell death is that SMF might inhibit DNA repair procedures [43,44]. Thus DNA damage induced by topoisomerase I inhibitor, doxorubicin, will not be repaired and cells will commit suicide, probably by induction of one or more of the ER stress signaling arms [42].

\section{Conclusions}

Collectively, these results indicate that intra-tumor implantation of $\mathrm{Fe}_{2} \mathrm{O}_{3}$ followed by exposure to a SMF and doxorubicin might provide a promising approach in the treatment of patients with breast cancer and for those being refractory to doxorubicin. This is strongly supported by previous findings, indicating that iron oxide particles have long blood retention rates and are biodegradable [5].

\section{Abbreviations}

DMSO: Dimethyl sulfoxide; DMEM: Dulbecco's modified Eagle's medium; ER: Endoplamic reticulum; FCS: FACScan flow cytometer; MRI: Magnetic resonance imaging; PVP: Polyvinyl pyrorolidone; ROS: Reactive oxygen species; SEM: Scanning electron microscope; SE: Standard Error; SMF: Static magnetic field; UPR: Unfolded protein response; XRD: X-ray diffraction.

\section{Competing interests}

The authors declare that they have no competing interests.

\section{Acknowledgements}

We would like to acknowledge Jordan University of Science \& Technology, Irbid; Jordan, for its financial support (grant number 226-2009). We thank Mrs. Mariya Komartsova for editing this manuscript.

\section{Author details}

${ }^{1}$ Biophysics laboratory, Jordan University of Science and Technology, Irbid, Jordan. ${ }^{2}$ Magnetic measurements laboratory, Jordan University of Science and Technology, Irbid, Jordan. ${ }^{3}$ Faculty of Pharmacy, University of Science and Technology, Irbid, Jordan.

\section{Authors' contributions}

All authors substantially contributed to the manuscript and approved the final submission.

Received: 30 May 2011 Accepted: 25 April 2012

Published: 25 April 2012

\section{References}

1. Pecorelli S, Favalli G, Zigliani L, Odicino F: Cancer in women. Int J Gynaecol Obstet 2003, 82:369-379.

2. Ferlay J, Parkin DM, Steliarova-Foucher E: Estimates of cancer incidence and mortality in Europe in 2008. Eur J Cancer 2010, 46:765-781.

3. Desantis C, Siegel R, Bandi P, Jemal A: Breast cancer statistics, 2011. CA Cancer J Clin 2011, 2011:20134.

4. Jordan Breast Cancer Program http://www.jbcp.jo/node/14

5. Peng XH, Qian X, Mao H, Wang AY, Chen ZG, Nie S, Shin DM: Targeted magnetic iron oxide nanoparticles for tumor imaging and therapy. Int J Nanomed 2008, 3:311-321.

6. Minotti G, Menna P, Salvatorelli E, Cairo G, Gianni L: Anthracyclines: molecular advances and pharmacologic developments in antitumor activity and cardiotoxicity. Pharmacol Rev 2004, 56:185-229.

7. Singal PK, lliskovic N: Doxorubicin-induced cardiomyopathy. N Engl J Med 1998, 339:900-905.

8. Amstad E, Textor M, Reimhult E: Stabilization and functionalization of iron oxide nanoparticles for biomedical applications. Nanoscale 2011, 3:2819-2843.

9. Loo C, Lowery A, Halas N, West J, Drezek R: Immunotargeted nanoshells for integrated cancer imaging and therapy. Nano Lett 2005, 5:709-711.

10. Park SI, Kwon BJ, Park JH, Jung H, Yu KH: Synthesis and characterization of 3-[1311]iodo-L-tyrosine grafted Fe3O4@SiO2 nanocomposite for single photon emission computed tomography (SPECT) and magnetic resonance imaging (MRI). SO-J Nanosci Nanotechnol 2011, 11:1818-1821.

11. Qu X, Wang J, Zhang Z, Koop N, Rahmanzadeh R, Huttmann G: Imaging of cancer cells by multiphoton microscopy using gold nanoparticles and fluorescent dyes. J Biomed Opt 2008, 13:031217.

12. Sosnovik DE, Nahrendorf M, Weissleder R: Magnetic nanoparticles for MR imaging: agents, techniques and cardiovascular applications. Basic Res Cardiol 2008, 103:122-130.

13. Ajima K, Yudasaka M, Murakami T, Maigne A, Shiba K, lijima S: Carbon nanohorns as anticancer drug carriers. Mol Pharm 2005, 2:475-480.

14. Cho K, Wang X, Nie S, Chen ZG, Shin DM: Therapeutic nanoparticles for drug delivery in cancer. Clin Cancer Res 2008, 14:1310-1316.

15. Gong X, Peng S, Wen W, Sheng P, Li W: Design and fabrication of magnetically functionalized core/shell microspheres for smart drug delivery. Adv Funct Mater 2009, 19:292-297.

16. Souza GR, Christianson DR, Staquicini Fl, Ozawa MG, Snyder EY, Sidman RL, Miller JH, Arap W, Pasqualini R: Networks of gold nanoparticles and bacteriophage as biological sensors and cell-targeting agents. Proc Natl Acad Sci USA 2006, 103:1215-1220. 
17. Yu MK, Jeong YY, Park J, Park S, Kim JW, Min JJ, Kim K, Jon S: Drug-loaded superparamagnetic iron oxide nanoparticles for combined cancer imaging and therapy in vivo. Angew Chem Int Ed Engl 2008, 47:5362-5365.

18. Chen J, Wang D, Xi J, Au L, Siekkinen A, Warsen A, Li ZY, Zhang H, Xia Y, Li $X$ : Immuno gold nanocages with tailored optical properties for targeted photothermal destruction of cancer cells. Nano Lett 2007, 7:1318-1322.

19. DeNardo SJ, DeNardo GL, Miers LA, Natarajan A, Foreman AR, Gruettner C, Adamson GN, Ivkov R: Development of tumor targeting bioprobes (111) In-chimeric L6 monoclonal antibody nanoparticles) for alternating magnetic field cancer therapy. Clin Cancer Res 2005, 11:7087s-7092s.

20. Dennis CL, Jackson AJ, Borchers JA, Hoopes PJ, Strawbridge R, Foreman AR, van Lierop J, Gruttner C, Ivkov R: Nearly complete regression of tumors via collective behavior of magnetic nanoparticles in hyperthermia. Nanotechnology 2009, 20:395103.

21. Hirsch LR, Stafford RJ, Bankson JA, Sershen SR, Rivera B, Price RE, Hazle JD, Halas NJ, West JL: Nanoshell-mediated near-infrared thermal therapy of tumors under magnetic resonance guidance. Proc Natl Acad Sci USA 2003, 100:13549-13554.

22. Liu T-Y, Liu K-H, Liu D-M, Chen S-Y, Chen I-W: Temperature-sensitive nanocapsules for controlled drug release caused by magnetically triggered structural disruption. Adv Funct Mater 2008, 18:1-8.

23. Maier-Hauff K, Rothe R, Scholz R, Gneveckow U, Wust P, Thiesen B, Feussne A, von Deimling A, Waldoefner N, Felix R, Jordan A: Intracranial thermotherapy using magnetic nanoparticles combined with external beam radiotherapy: results of a feasibility study on patients with glioblastoma multiforme. J Neurooncol 2007, 81:53-60.

24. Bae JE, Huh MI, Ryu BK, Do JY, Jin SU, Moon MJ, Jung JC, Chang Y, Kim E, Chi SG, Lee GH, Chae KS: The effect of static magnetic fields on the aggregation and cytotoxicity of magnetic nanoparticles. Biomaterials 2011, 32:9401-9414.

25. Mhaidat NM, Zhang XD, Allen J, Avery-Kiejda KA, Scott RJ, Hersey P: Temozolomide induces senescence but not apoptosis in human melanoma cells. Br J Cancer 2007, 97:1225-1233.

26. Gillespie SK, Zhang XD, Hersey P: Ingenol 3-angelate induces dual modes of cell death and differentially regulates tumor necrosis factor-related apoptosis-inducing ligand-induced apoptosis in melanoma cells. $\mathrm{Mol}$ Cancer Ther 2004, 3:1651-1658.

27. Box HC, Maccubbin AE: Lipid peroxidation and DNA damage. Nutrition 1997, 13:920-921.

28. Meneghini R: Iron homeostasis, oxidative stress, and DNA damage. Free Radic Biol Med 1997, 23:783-792.

29. Grzegorczyk J: Apoptosis-programmed cell death (PCD)—current conceptions. Int J Biomed Res 1999, 1:2-7.

30. Jajte JM: Chemical-induced changes in intracellular redox state and in apoptosis. Int J Occup Med Environ Health 1997, 10:203-212.

31. Kerr JF, Wyllie AH, Currie AR: Apoptosis: a basic biological phenomenon with wide-ranging implications in tissue kinetics. Br J Cancer 1972, 26:239-257.

32. Sarafian TA, Bredesen DE: Is apoptosis mediated by reactive oxygen species?. Free Radical Res 1994, 21:1-8.

33. Lai $\mathrm{H}$, Singh NP: Acute exposure to a $60 \mathrm{~Hz}$ magnetic field increases DNA strand breaks in rat brain cells. Bioelectromagnetics 1997, 18:156-165.

34. Singh $\mathrm{N}$, Lai $\mathrm{H}: 60 \mathrm{~Hz}$ magnetic field exposure induces DNA crosslinks in rat brain cells. Mutat Res 1998, 400:313-320.

35. Zmyslony M, Palus J, Jajte J, Dziubaltowska E, Rajkowska E: DNA damage in rat lymphocytes treated in vitro with iron cations and exposed to $7 \mathrm{mT}$ magnetic fields (static or 50Hz). Mutat Res 2000, 453:89-96.

36. Hisamitsu T, Narita K, Kasahara T, Seto A, Yu Y, Asano K: Induction of apoptosis in human leukemic cells by magnetic fields. Jpn J Physiol 1997 47:307-310.

37. Reipert BM, Allan D, Reipert S, Dexter TM: Apoptosis in haemopoietic progenitor cells exposed to extremely low-frequency magnetic fields. Life Sci 1997, 61:1571-1582

38. Simko M, Kriehuber R, Weiss DG, Luben RA: Effects of $50 \mathrm{~Hz}$ EMF exposure on micronucleus formation and apoptosis in transformed and nontransformed human cell lines. Bioelectromagnetics 1998, 19:85-91.

39. Blumenthal NC, Ricci J, Breger L, Zychlinsky A, Solomon H, Chen GG, Kuznetsov D, Dorfman R: Effects of low-intensity AC and/or DC electromagnetic fields on cell attachment and induction of apoptosis. Bioelectromagnetics 1997, 18:264-272.
40. Sarvestani AS, Abdolmaleki P, Mowla SJ, Ghanati F, Heshmati E, Tavasoli Z, Jahromi AM: Static magnetic fields aggravate the effects of ionizing radiation on cell cycle progression in bone marrow stem cells. Micron 2010, 2:101-104

41. Chionna A, Dwikat M, Panzarini E, Tenuzzo B, Carla EC, Verri T, Pagliara P, Abbro L, Dini L: Cell shape and plasma membrane alterations after static magnetic fields exposure. Eur J Histochem 2003, 47:299-308.

42. Mhaidat NM, Alali FQ, Matalqah SM, Matalka II, Jaradat SA, Al-Sawalha NA, Thorne RF: Inhibition of MEK sensitizes paclitaxel-induced apoptosis of human colorectal cancer cells by downregulation of GRP78. Anticancer Drugs 2009, 20:601-606.

43. Chow K, Tung WL: Magnetic field exposure enhances DNA repair through the induction of DnaK/J synthesis. FEBS Lett 2000, 478:133-136.

44. Robison JG, Pendleton AR, Monson KO, Murray BK, O'Neill KL: Decreased DNA repair rates and protection from heat induced apoptosis mediated by electromagnetic field exposure. Bioelectromagnetics 2002, 23:106-112.

doi:10.1186/1477-7819-10-62

Cite this article as: Aljarrah et al:: Magnetic nanoparticles sensitize MCF-7 breast cancer cells to doxorubicin-induced apoptosis. World Journal of Surgical Oncology 2012 10:62.

\section{Submit your next manuscript to BioMed Central and take full advantage of:}

- Convenient online submission

- Thorough peer review

- No space constraints or color figure charges

- Immediate publication on acceptance

- Inclusion in PubMed, CAS, Scopus and Google Scholar

- Research which is freely available for redistribution 